\title{
Does Informal Knowledge Sharing Breed Innovation in Industrial Clusters?*
}

\author{
Ayşe Elif Şengün \\ Ylldırım Beyazlt University
}

\begin{abstract}
This study investigates the influence of informal knowledge sharing on the innovative performance of individual firms in an industrial cluster. By informal knowledge sharing, we mean to imply the knowledge that is shared automatically, indirectly, accidentally and unknowingly by firms in a geographically bounded area as part of the know-how common to all members in the cluster. To capture this 'informality.', we investigate the impact of trust-based knowledge sharing. In this respect, we associate trust-based knowledge sharing between furniture manufacturers and furniture retailers to their innovative performance. While doing this, we make use of both qualitative and quantitative methods. Data from 220 manufacturers and 137 retailers suggest no association between informal knowledge sharing and innovative performance. We discuss our findings with respect to the interaction between contextual specifics and innovative effectiveness of knowledge sharing. Further, we try to identify those elements in the institutional environment of the cluster that are unfavorable to the production of innovation.
\end{abstract}

Keywords: informal knowledge sharing, innovation, clusters, furniture industry, horizontal exchange, Turkey.

\section{Endüstriyel Kümelerde Sosyal Bilgi Paylaşımı Yenilikçilik Yaratır mı?}

\section{Özet}

$\mathrm{Bu}$ çalışma endüstriyel kümelerde sosyal bilgi paylaşımının firmaların yenilikçi performansı üzerine etkisini araştırmaktadır. Sosyal bilgi paylaşımından kastımız, kümelenmenin yarattığ 1 ortak bilgiye istinaden belli bir coğrafi alanda faaliyet gösteren firmalar tarafindan dolaysız, kazara ve belli bir amaç güdülmeden adeta otomatik olarak paylaşılan bilgidir. Paylaşılan bilginin 'sosyal' doğasını daha iyi yansıtmak adına güvene dayalı bilgi paylaşımı incelenmektedir. Bu anlamda mobilya imalatçıları ve mobilya mağazacıları arasındaki güvene dayalı bilgi paylaşımının bu firmaların yenilikçi performansına etkisi arasında ilişki kurulmuştur. Bunun için hem nitel hem de nicel yöntemler kullanılmıştır. 220 imalatçı ve 137 mağazacı firmadan elde edilen

\footnotetext{
* This study was completed as part of a larger research project funded by The Scientific and Technological Research Council of Turkey (Project no.: SOBAG 105K168).

** Ayşe Elif Şengün is an Associate Professor in the Department of Management at Yıldırım Beyazıt University, Cinnah Caddesi 16/A, Çankaya, Ankara, Turkey. E-mail: ayseelifs@yahoo.com and sengun@ybusm.info
} 
veriler sosyal bilgi paylaşımının yenilikçilik üzerine etkisi olmadığını göstermektedir. Bulgularımızı bağlamın kendine has özellikleri ile bilgi paylaşımının yenilikçiliğe katkısı arasındaki etkileşimleri birlikte düşünerek tartışmaktayız. Aynı zamanda kümenin kurumsal ortamının yenilikçilik üretmeye yatkın olmayan unsurlarını da ele alıyoruz.

Anahtar kelimeler: sosyal bilgi paylaşımı, yenilikçilik, endüstriyel kümeler, mobilyacılık, yatay mübadele, Türkiye.

$\mathrm{T}$ This study aims at investigating the influence of informal knowledge sharing on the innovative performance of firms in an industrial cluster. By informal knowledge sharing we mean to imply the more or less automatic, haphazard, indirect, unintended or accidental knowledge accrued by members of a cluster via mere membership or 'being there' (Bathelt, Malberg, and Maskell, 2004; Tallman et al., 2004). Such knowledge can be accessed through participation in the various social gatherings of the cluster.

The literature on industrial clusters relates inter-firm cooperation to mutual interdependence (e.g., Schmitz, 1995; Rabelotti, 1995; Visser, 1999; You and Wilkinson, 1994). According to this, territorial proximity in a cluster provides opportunities for small entrepreneurs to take a specialist position in the production of various parts and components and hence a division of labor among firms ensues. Consequently, because no firm incorporates the internal capacity and knowledge to cover all the operations efficiently, each draws on another to compensate for its disadvantage in the form of resources, operations, and knowledge. This aspect is also called the 'collective efficiency' of clusters (Schmitz 1995, 1999). This collectivity results in the structuring of the cluster as a social system. And this social structure gives way to the creation of competences and capabilities that derive from the ensemble of internal relations and its associated rules and practices (Lawson, 1999). Marshall calls this ensemble the general climate or 'industrial atmosphere' within a cluster. According to him, firms in a cluster will benefit from this industrial atmosphere in various ways one of which is access to 'knowledge in the air' or cluster-level knowledge (Bellandi, 1989). This access, in turn, is enabled via the shared conventions, rules, and languages for developing, sharing, and interpreting knowledge in the industrial milieu (Lawson, 1999). Resultantly, firms benefit from this amassed knowledge unknowingly, automatically, indirectly and accidentally, through mere membership in the cluster (Tallman et al., 2004).

Because knowledge simply flows or 'spills' over member firms, it is considered an 'untraded interdependence', meaning that it is not a benefit in the form of economies of scale or low cost transportation (i.e., traded interdependence), but rather, a product of the local socio-institutional setting (e.g., shared conventions, rules, language, traditions, habits, etc.) and associated inter-firm communication, interaction and learning (Lawson, 1999; Storper, 1995).

This study aims to contribute to existing research by empirically addressing the question of what impact this automatic, haphazard, indirect, unintended or accidental 
knowledge that firms in a cluster share unknowingly has on their innovative performance, a hitherto neglected domain. Although previous research on industrial clusters laid the theoretical foundation on the role of knowledge sharing or spillovers in innovation (e.g., Becattini, 2004; Bellandi, 1989; Cooke, Gomez, and Etxebarrria, 1997; Dei Ottati, 1994, 2003; Marshall, 1952), empirical work on the topic has been rare. Interestingly, research in the field has not been so keen to specifically associate knowledge spillovers to firm level innovative performance (Gilbert, McDougall, and Audretsch, 2008). ${ }^{[1]}$ What's more, extant theory on industrial clusters tended to take the effectiveness of inter-firm knowledge sharing as granted and this served to widen the gap between theory and empirical evidence on the subject (Arıkan, 2009). Bathelt et al. (2004) raise similar concerns over the assumption that co-location and frequent contact will yield better knowledge sharing. Also, Oinas (1999) points at the scarcity of systematic empirical analysis dealing with actual learning processes within clusters to give support to claims about 'localized learning'.

To our knowledge, there is no study that explicitly associates informal knowledge sharing with the innovative performance of individual firms in a cluster environment. By exploring this topic we also aim to put the well-established theoretical assumption on the effectiveness of knowledge spillovers on innovation under test and, in that sense, provide a timely response to a recent call in the popular press towards more verification on earlier scientific claims (Economist, October 19, 2013).

In order to capture the essence of informal knowledge sharing, we opted to explore the impact of knowledge shared among firms in a cluster during social gatherings such as having lunch or meeting over tea. In that respect, we benefited from the relational lubricant role of trust that is known to facilitate face-to-face contact and the transmission of even non-articulated knowledge forms. So, we include trust as a predictor of knowledge sharing in our theoretical model (Figure 1). Additionally, we focus on communication among firms in horizontal exchange relationships rather than vertical buyer-supplier relationships. The rationale behind this is that, in buyer-supplier relationships, the knowledge shared will be aimed more at achieving a certain desired end such as materials procurement, design, production, or distribution and hence will be more purposive and direct with a goal of exchanging value-for-value. However, this would not coincide with our study aims since we desire to represent 'informality' in the sense of not seeking an explicit compensation from the other party (Tallman et al., 2004). As such, we concentrate only on manufacturer-manufacturer and retailerretailer horizontal exchanges.

[1] Two studies, the one by Jaffe et al. (1993) and Frost (2001) need to be mentioned here as exceptions. In the first case, Jaffe et al. (1993) explore the extent to which citations to patents held by other institutions tend to have a localized pattern or not. In the second study, Frost (2001) traces the sources utilized by subsidiary firms of multinational companies while generating innovations. He seeks to understand if knowledge from the host country in which the subsidiaries operate has an advantage over knowledge that resides in the parent country while a subsidiary firm innovates. Although both of the studies aim to demarcate the regional pattern of knowledge spillovers, none focus on informal knowledge sharing or industrial clusters. 


\section{Literature Review}

Starting from the 1980s, scholars and policy makers have been paying more and more attention on regional industrial agglomerations. According to Isaksen (2001), the reason behind this popularity is that since the 1970s different types of industrial agglomerations or clusters have established a strong position in world markets in both traditional (e.g., Third Italy) and high technology products (e.g., Silicon Valley). Hence, industrial clusters have come to be seen as sites of competitive advantage. As a way to explain this superior competitiveness, economic perspectives emphasized the role of positive externalities such as low cost transportation, enhanced productivity and economies of scale. Another example to the economic understanding is presented by Porter (1998) who views competitiveness in clusters as an outcome of better access to specialized and experienced employees, suppliers, specialized information and public goods, the motivating force of local rivalry and sophisticated customers.

However, these approaches are criticized for seeing the cluster principally as a 'container' of spatially proximate elements rather than a dynamic evolving structure (Asheim et al., 2003). Alternative approaches focus on the important role played by the social, institutional and cultural elements in the cluster (e.g., Becattini, 2004; Lawson, 1997; Storper 1995). According to this, inter-firm relations, and not their mere co-location, are the defining factors of a cluster (Isaksen, 2001). For example, Leonardi (1995) proposes that the economic development of Central and Northern Italy was a result of collective action and cooperation among firms in these regions, which came to life through the widespread presence of social capital and mutual trust. Similarly, the 'Nordic School' of regional learning (e.,g., Lundvall 1992; Asheim, 2002; Asheim and Coenen, 2005; Asheim, Coenen, and Henning, 2003) highlights the significance of the cultural and institutional context of the cluster for the promotion of innovation. According to this, knowledge is inserted in the various interpersonal and inter-organizational networks within the cluster, which makes it 'sticky' or grounded in the local routines, norms, practices, and social interactions.

Hence, the explanations for the competitiveness of clusters have increasingly come to be associated with socio-cultural elements such as inter organizational relations. And among the aspects of this competitiveness, localized learning and innovation have gained particular attention (e.g., Porter, 1998; Keeble and Wilkison, 1999; Baptista and Swann, 1998; Lawson, 1999). According to Asheim et al. (2003), the reason behind this is that 'competitiveness' as a term signifies something dynamic, which is mostly achieved by innovation policies. Thus, innovation plays a central role in attaining and sustaining competitive advantage and therefore the distinction between 'competitiveness' and 'innovativeness' becomes irrelevant.

In today's globalizing economy, knowledge is identified as the most strategic resource for firm competitiveness and innovation is treated as an interactive learning, knowledge creating process. Bathelt et al. (2004) explain this interactive process as one where actors processing different types of knowledge and competitiveness come together to exchange information with the aim of solving technical, organizational, commercial or intellectual 
problems. Because industrial clusters embody firms with similar or related economic activity and member firms reside in the same local environment and meet repeatedly in person, the opportunities to exchange subtle forms of knowledge are enhanced. One fundamental reason for this is that frequent contact and familiarity facilitates trust between exchange parties, which in turn gives way to the transmission of more complex, sticky, non-articulated, tacit forms of knowledge (Hansen, 1999), very important for the production of innovation (Amara and Landry, 2005: 249; Caloghirou et al., 2004: 32).

With reference the relevant literature, Bathelt et al. (2004) identify another important source for new knowledge creation and innovation accrued solely via co-location in an industrial cluster. Also labeled 'local buzz', this refers to the information and communication ecology created by face-to-face contacts, co-presence and co-location of people and firms. Those who participate in the social and economic spheres of the cluster receive it more or less automatically, as it is unavoidable to eavesdrop to gossip, rumors and news about other firms in the same locale. Diffusion of such 'buzz' can be blocked, however, if distrust and malfeasance characterize social relations among actors.

\section{Background on the Research Setting}

Although there is an abundance of definitions offered in the literature to define industrial clusters, three overriding characteristics can be said to exist: the predominance of small and medium sized enterprises (Saxenian, 1994), geographic concentration (Marshall, 1952), and the presence of both competition and cooperation amongst firms (Porter, 1998). Following Öz (2004), ${ }^{[2]}$ we define an industrial cluster as a geographically concentrated network including interconnected small and medium sized companies, other companies in related industries, and institutions such as universities, trade associations, and vocational training providers.

As Öz (2004) explains, the city of Ankara hosts three furniture clusters, namely, Siteler, Akyurt, and Sincan. Among these, Siteler is the one with the highest concentration of firms and related industries, so that it stands for the entire furniture cluster in Ankara and thereby represents the major furniture cluster in Turkey. Siteler satisfies the conditions for being an industrial cluster from a number of respects. First and foremost, it has the highest Location Quotient (LQ) - calculated in terms of the extent to which firms are agglomerated in a particular locale- among other competing furniture agglomerations in Turkey. Apart from this, its proximity to major public offices and institutions, such as the parliament, ministries, the central bank, regulatory bodies, head of general staff of armed forces, etc. create vast advantage as per high quality or 'sophisticated' (Porter, 1998) demand. Thirdly, it conforms to Porter's cluster definition in the sense that there is a strong related industry, the construction industry, in Ankara. This related industry not only fuels demand, but also supports mutual learning and innovation for the furniture cluster in Siteler. Moreover, Ankara's geographically central location in the country and

[2] The reason why we adopt this definition among others is that this work encompasses a qualitative study of four industrial clusters in Turkey, one of which is the Siteler furniture cluster in Ankara, the field of the current study. 
its less humid climate provides two positive externalities with respect to transportation and production of furniture respectively. The city also hosts four public universities that have furniture production and industrial design departments.

Historically, the Ankara Siteler furniture cluster can be said to have undergone cycles of up and down swings of performance. Beginning as a sub-cluster in the 60 acres of land allocated mainly to timber merchants in the late 1950s, the cluster saw its heyday around mid 1970s until the late 1980s when it managed to achieve a regional and national recognition (Özen et al., 2007). Because this early success could not be sustained in the face of domestic rivalry by similar furniture clusters in other parts of Turkey, liberalization of imports, and the ensuing international competition, the reputation of the cluster began to erode (Öz, 2004). Today the cluster's operations is dispersed over 5.000 acres of land with 5.000 firms under record and despite the bleak prospects of the mid 1990s, the three furniture clusters, including Siteler, in the city of Ankara have more than quadrupled their export performance since the beginning of 2000s (Ankara Kalkınma Ajans1, 2012). Thus, these figures reflect an optimistic outlook as regards the future of furniture in the area.

Our qualitative analysis (described in the 'Methods' section) suggests that the Ankara Siteler furniture cluster members enjoy some important advantages that might positively impact their innovative potential. As an example, cluster firms can effortlessly reach any type of raw material or factor of production (i.e., coating, metal parts, glass, fabric, rubber, fiberboard, timber, leather, sanding material, painting material, small hardware items, etc.), semi-finished product (i.e., furniture in skeleton form) or skilled master craftsmen. Moreover, inter-firm exchanges are governed by informal arrangements (or 'open account' basis as the cluster members phrase it), which eliminate the need for costly contractual arrangements. Such relational arrangements are said to ease the way the business runs by allowing the payment balance to be reached over a series of exchanges rather than instantaneously. This way, SME owners can take bold innovative moves without bothering about the possible liquidity constraints such initiatives might bring.

\section{Theoretical Model and Research Hypotheses}

\section{Trust and Knowledge Sharing}

In general, the primary direct benefit of trust is considered to be the facilitation of access to new and broader sources of information (Adler and Kwon, 2002; Nahapiet and Ghoshal, 1998). For example, a network of relations based on trust can transmit richer information than other types of networks (Krackhardt and Hanson, 1993). Trust has consistently been found to be a critical factor in inter-organizational knowledge sharing relationships (Pardo, Cresswell, Zhang, and Thompson, 2001). In the context of industrial clusters, geographic proximity facilitates knowledge transfer and technical information flow and inter-firm relationships are based on expectations of trust and norms of reciprocity, where firms observe and remember the past behaviors of members and punish those who behave inappropriately by social disapproval (Dei Ottati, 1994). These aspects of the context diminishes the risk of exploitation and enhances 
positive assessments of the other party's benevolence, which brings stronger bonds of trust between actors. Consequently, actors become more willing to accept the risks of spillovers to competitors that may ensue from sharing knowledge across organizations with differing goals and competing interests (Dyer and Singh, 1998). Thus, trust plays a key role in the knowledge sharing decisions of actors.

According to our qualitative analysis, because furniture firms in the Ankara Siteler cluster divide production processes among each other, the ensuing division of labor inadvertently brings about knowledge sharing on technology, trends, strategy, and the like. However, participants also raise concerns about their designs being imitated by others. This fear over free riding reduces inter-firm cooperation only to an in group of firms whose owners are also friends and are therefore trusted not to be opportunistic. Hence, knowledge sharing becomes dependent on trust between exchangers. The following quote illustrates this point:

Now we have this motto: "A furniture maker cannot have a furniture maker friend". We may talk about everything such as prices, where the product comes from, etc., but we generally do not visit each other's store. Even if we do, we talk what we have to talk at the entrance and leave. We try not to stare at the furniture inside. This is commercial ethics. However, I exchange information with those that I find close and trust [...] we may talk about everything such as prices, where the product comes from, etc. [...] We may go to fairs together, I may tell them about the new models I see, recommend certain ways of working and cost reduction, the design trends, a certain type of fabric used by the Italians, etc. We surely share this type of knowledge ( $9^{\text {th }}$ respondent).

Hence we posit:

H1: Trust between firms in an industrial cluster leads to better knowledge sharing.

H1a: The more manufacturer firms trust in each other the more will they share knowledge.

$\mathrm{H} 1 \mathrm{~b}$ : The more retailer firms trust in each other the more will they share knowledge.

\section{Knowledge Sharing and Innovation}

Conventional resource-based-view of the firm holds that innovating firms that protect their knowledge base from other firms can achieve a competitive edge and perform better than those that share knowledge (Spencer, 2003). Contemporary wisdom or the relational view (Dyer and Singh, 1998) complements this proprietary perspective by arguing that a firm's critical resources may span out of its boundaries and this may make it necessary to ally with other firms. This would also enable the generation of relational rents via the sharing of knowledge with other firms (Lavie, 2006). When coupled with the ease of information flow due to geographical proximity in a cluster environment, such a rent making possibility translates into higher innovative performance for firms through the sharing of knowledge (Audretsch and Feldman, 1996; Baptista and Swann, 1998; Caloghirou, Kastelli, and Tsakanikas, 2004; Ibrahim and Fallah, 2005; Spencer, 2003). 
Research on industrial clusters indicates higher innovation competence for firms exchanging information with others both in developed (Gellynck, Vermeir, and Viaene, 2007) and developing countries (Geenhuizen and Indarti, 2006). Moreover, studies of innovation systems in metropolitan areas show spatial proximity to be critical for the effectiveness of knowledge sharing between firms (Revilla-Diez, 2002). Furniture making industry provides a good case in point. As Beerepoot (2008) explains, because furniture is a traditional low-tech industry, the knowledge that is exchanged still remains mainly tacit. ${ }^{[3]}$ and this, in turn, makes firms dependent on informal personal relationships and thereby closer proximity for its transfer. In compliance with this, Eraydın and Köroğlu (2005) find local firms in close proximity to be a very valuable knowledge source for innovation in traditional low-tech industries in Turkish industrial clusters.

The findings from the qualitative phase of this study also demonstrate the important role of knowledge sharing in cluster firms' perspectives on innovative prospects. Firm representatives clearly affirm the significance of knowledge sharing for their ability to 'solve problems' and 'visualize the future'. They say they share operational and practical insights on the routine day-to-day operations as well as visions and trends among friends off the job, during social gatherings, such as having lunch or a cup of tea together. The following quotes are illustrative:

A lot can be gained from sharing [knowledge], particularly in the professional sense. Because you can take painting technology one-step further by sharing [knowledge] with another, you can change colors, shapes, or find a chance for application in another domain. In my opinion, people can gain much by benefiting from this. However, if you live with a 'you-me' type of ego, it [knowledge] will only remain with you and end when you stop, it will never be developed further (8th respondent).

We are a group of people with the same culture together in [cluster name]. We are people from the same social strata who do the same business. We sit down and talk to each other. We share experiences that we have. And we would know what to talk about because we are at the same knowledge level. We really do share knowledge [...] When we see certain [furniture] models, we tell our friends $[\ldots]$ we tell them how to work in a certain way, how to reduce costs, we tell about all these ( $9^{\text {th }}$ respondent)

I would share knowledge on fabrics. The fabric seller would also help us [...] for example concerning customer preferences [...] he would advice fabrics that would fit our designs, he would advice certain colors $[\ldots]\left(8^{\text {th }}\right.$ respondent $)$.

Hence we posit:

$\mathrm{H} 2$ : Knowledge sharing between firms in an industrial cluster leads to better firmlevel innovative performance.

[3] Although all knowledge that is shared has a tacit element notwithstanding the type of technology, explicit codes for knowledge to be exchanged exist in high-tech industries. Traditional industries such as low-tech furniture, on the other hand, depend more on craft skills, which renders the knowledge to be exchanged even more tacit. 
H2a: The higher the knowledge sharing between manufacturer firms the higher will be their innovative performance.

$\mathrm{H} 2 \mathrm{~b}$ : The higher the knowledge sharing between retailer firms the higher will be their innovative performance.

Based on the two groups of hypotheses above we postulate that informal knowledge sharing among firms in a cluster leads to better innovative performance. This theoretical model is summarized in Figure 1 below.

Figure 1

\section{Theoretical Model}

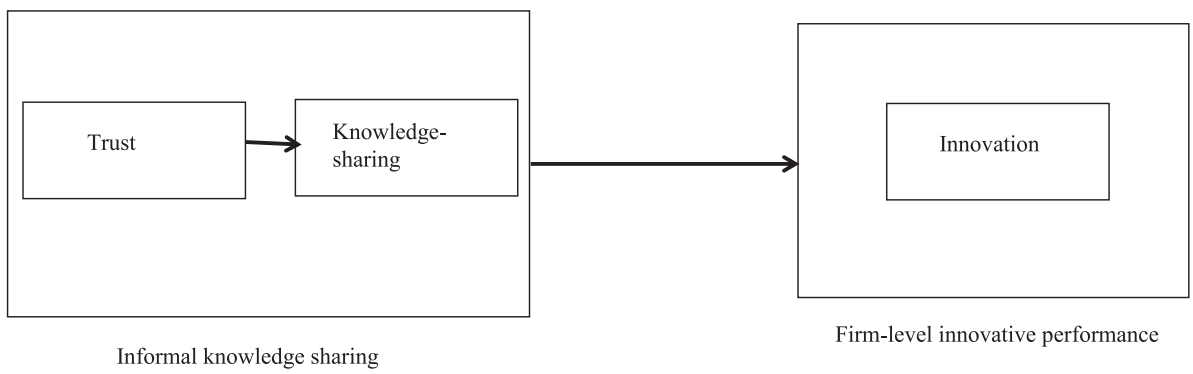

\section{Methods}

Our theoretical model and hypotheses were tested with data from SMEs producing furniture in Ankara Siteler cluster. Our sample consists of two fundamental firm types involved in innovative activities: Manufacturers and retailers. Manufacturers define those firms that actually produce a certain furniture item partly or totally in their workshop for resale. Retailers, on the other hand, are those firms that produce a certain furniture item partly or totally in their workshop and sell both these items and those produced by a manufacturer firm on their behalf. Both types of firms produce finished furniture items such as tables, chairs, sofas, cupboards, cabinets. They also make semi-finished or preassembled whole parts such as table structures, bed frames or other furniture parts.

We adopt a sequential methodological approach such that the qualitative phase informs the quantitative phase of the analysis (i.e., measure selection, adaptation and creation) and hypotheses development (Schultz and Hatch, 1996). In this respect, the qualitative part was aimed at understanding the intricacies of informal knowledge sharing and innovation between two different types of firms.

\section{Qualitative Analysis}

Twenty-four semi-structured in-depth interviews were conducted each lasting about one and a half hours on average. We decided to include members from different phases of the furniture value-chain (i.e. procurement, manufacture, retail, institutional/governmental bodies) (Table 1). To this end, we made use of personal acquaintances as references or gatekeepers. The rest of the respondents other than these initial references were reached with the help of the interviewees. After completing an interview, we asked the inter- 
viewee to refer us to another cluster member. This way, we completed the twenty-four interviews between May-November 2006. They were transcribed into texts, then coded and interpreted according to the procedures of content analysis described in Coffey and Atkinson (1996) and Berg (1998).

Table 1

Qualitative Sample Structure

\begin{tabular}{|c|c|c|c|}
\hline Respondent \# & $\begin{array}{c}\text { Business Area of the Firm / Institution } \\
\text { (regulatory / supplier / Retailer) }\end{array}$ & Firm Size & Positions of Interviewees \\
\hline 1 & State Institution (KOSGEB) & n.a & $\begin{array}{c}\text { Business Development Manager } \\
\text { Specialist } \\
\text { Specialist } \\
\text { Specialist }\end{array}$ \\
\hline 2 & $\begin{array}{c}\text { Professional Association } \\
\text { (Woodworking Federation and the } \\
\text { Chamber of Furnishers and Lacquerers) }\end{array}$ & n.a & $\begin{array}{c}\text { Head of Woodworking Federation } \\
\text { and the Chamber of Furnishers and } \\
\text { Lacquerers }\end{array}$ \\
\hline 3 & $\begin{array}{l}\text { Independent Business Association } \\
\text { (MÜSİAD) }\end{array}$ & n.a & $\begin{array}{c}\text { Branch Officer } \\
\text { Specialist }\end{array}$ \\
\hline 4 & Retailer & Large $^{1}$ & $\begin{array}{l}\text { Firm Owner } \\
\text { Firm Owner }\end{array}$ \\
\hline 5 & Retailer & Large & Firm Owner \\
\hline 6 & Retailer & $\begin{array}{l}\text { Both } \\
\text { Small }\end{array}$ & $\begin{array}{l}\text { Marketing Manager } \\
\text { Manufacturer }\end{array}$ \\
\hline 7 & Retailer & Medium & Firm owner \\
\hline 8 & Retailer & Large & Store Manager \\
\hline 9 & Retailer & Medium & Firm Owner \\
\hline 10 & Retailer & Large & Firm Owner \\
\hline 11 & Retailer & Large & Firm Owner \\
\hline 12 & Retailer & Large & Firm Owner \\
\hline 13 & Retailer & Large & Firm Owner \\
\hline 14 & Manufacturer & Small & Firm Owners (father and son) \\
\hline 15 & Manufacturer & Small & Firm Owners \\
\hline 16 & Manufacturer & Small & Firm Owner \\
\hline 17 & Manufacturer & Small & Firm Owner \\
\hline 18 & Manufacturer & Large & Firm Owner \\
\hline 19 & Supplier (Dye, hardware) & Large & Firm Owner \\
\hline 20 & Supplier (Draper) & Large & Firm Owner \\
\hline 21 & $\begin{array}{c}\text { Supplier } \\
\text { (Woodwork) }\end{array}$ & Large & Firm Owner \\
\hline 22 & $\begin{array}{c}\text { Supplier } \\
\text { (Woodwork) }\end{array}$ & Large & Firm Owner \\
\hline 23 & Retailer & Medium & Firm owner \\
\hline 24 & Retailer & Medium & Firm owner \\
\hline
\end{tabular}

${ }^{\prime}$ This categorization is based on a relative comparison of firm sizes within the specific cluster. Both cluster members and professionals agree that the largest firm is actually medium sized in terms of national standards. 


\section{Quantitative Analysis}

In this phase, a pilot test of the questionnaire was done in order to check the appeal of the cover letter, the interpretability of the construct items, and the utility of the scales before the actual collection of data. The pilot test was applied on a sample of 15 firms in the cluster and questionnaire items were revised in the light of the responses received.

Table 2

\section{Characteristics of the Samples}

\begin{tabular}{lcc}
\hline & MANUFACTURERS (\%) & RETAILERS (\%) \\
\hline $\begin{array}{l}\text { Education } \\
\text { Primary School }\end{array}$ & 52.7 & 34.7 \\
\hline Middle School & 20.5 & 20.7 \\
\hline High School & 21 & 24.7 \\
\hline Vocational High School & 1.8 & 2 \\
\hline University & 3.6 & 16.7 \\
\hline Grad School & 0.5 & 1.3 \\
\hline
\end{tabular}

Firm Age (year)

\begin{tabular}{lcc}
$<10$ & 43 & 22 \\
\hline $10-30$ & 43.7 & 62.7 \\
\hline $31-62$ & 9.3 & 15.3 \\
\hline
\end{tabular}

\section{District Experience (year)}

\begin{tabular}{lll}
$<10$ & 13.2 & 18.7 \\
\hline $10-30$ & 59.8 & 62.7 \\
\hline $31-50$ & 26.9 & 18.7 \\
\hline
\end{tabular}

Sector Experience (year)

\begin{tabular}{lll}
$<10$ & 10.5 & 16.7 \\
\hline $10-30$ & 62.1 & 64.7 \\
\hline $31-50$ & 27.4 & 18.7 \\
\hline
\end{tabular}

Number of employees

\begin{tabular}{lll}
$1-5$ & 85.9 & 38.7 \\
\hline $6-10$ & 11.4 & 30.7 \\
\hline $11-45$ & 2.9 & 30.7 \\
\hline
\end{tabular}

\section{Position in the firm}

\begin{tabular}{lll} 
Owner & 79.5 & 84 \\
\hline Professional manager & 20.5 & 16 \\
\hline $\begin{array}{l}\text { Effect on Decisions } \\
\text { Very effective }\end{array}$ & 76.8 & 77.4 \\
\hline Effective & 23.2 & 22.6 \\
\hline
\end{tabular}


The characteristics of the manufacturer and retailer samples are listed in Table 2. We selected the official website of the furniture cluster consisting of 6.000 firms as our sampling frame. 60 firms were selected randomly from this website, 40 of which turned out to be manufacturers and 20 to be retailers. Then the questionnaire was applied to these 60 randomly selected firms, named as the 'first phase' firms. To reach the rest of the firms, we benefited from 'snowballing'. That is, we asked each of the sixty firms that helped filling out the questionnaire to suggest a firm they worked with as a retailer or a manufacturer that they thought would cooperate. Irrelevant cases (i.e., a given manufacturer or retailer did not share knowledge with a competitor) were eliminated from the database. Three cases from the manufacturer sample, and thirteen cases from the retailer sample were thus eliminated. Furthermore, the $177^{\text {th }}$ case in the manufacturer sample was identified as an outlier and was eliminated from the sample. After all these adjustments there remained 220 manufacturers and 137 retailers in the sample.

During the qualitative interviews, the interviewees were asked whom we should contact in a given firm as key respondents. The interviewees generally agreed that owners, owner managers, and purchasing managers would be the most suitable. Thus, we chose key informants to be owners, general managers, and purchasing managers (the latter two positions existed only in larger firms) for the purpose of reducing single-informant bias (Zaheer, McEvily, and Perrone, 1998).

\section{Measures}

Measures were formed in the light of both theory and qualitative analysis. Based on our qualitative analysis we understood that trust between manufacturer firms tends to be based on friendship and close ties, whereas trust between retailers is based on nonopportunism as well as friendship and affection. In this respect, two questions reflecting friendship and affection components were adapted from Ganesan (1994) and McAllister (1995) for the manufacturer and retailer samples. Two questions that reflect the nonopportunism component were originally developed for the retailer sample.

Our qualitative analysis showed that manufacturers share operational and practical knowledge based on their insights on the routine day-to-day operations, whereas retailers share tactical or political knowledge or "visions and trends", as they put it. In this respect, we developed the manufacturer-to-manufacturer knowledge-sharing construct with an emphasis on 'mutual learning' with two questions from Kale, Singh, and Perlmutter (2000), and the one for retailers was developed originally with an emphasis on 'vision sharing' and much inspiration from Jap and Ganesan (2000).

As indicated in the theoretical model in Figure 1, the trust and knowledge sharing constructs altogether form the composite construct 'informal knowledge sharing'. To capture the essence of this composite construct, we made trust and knowledge sharing related with the former leading to the latter, since our respondents frequently stressed the importance of personal ties and friendship for informal communication. Additionally, we studied the knowledge shared between firms in a horizontal exchange relationship and not buyers and suppliers to ensure that it is not specifically directed at a value-for- 
value exchange purpose. Moreover, the firm members we studied were the ones that met frequently off the job in social gatherings (i.e., during lunch or over tea) to share insights with each other.

The qualitative phase indicated that innovative performance of firms in the current cluster would be characterized as one of three forms: product, process and marketing innovations. A review of the literature showed that the measure most suitable for the types of exchange in our context and the one that conforms to the norms of the Oslo Manual (2005) was the one by Weerawardena (2003). Three items for each of product, process, and marketing innovations were thus adopted.

\section{Operationalization}

The 'trust' and 'knowledge sharing' scales were measured on a five-point Likert-type scale (i.e., ranging from 'Strongly Disagree' to 'Strongly Agree'), and respondents were asked to keep in mind a retailer or manufacturer firm in the cluster with whom they frequently met off-the-job during social gatherings such as having lunch or a cup of tea.

The innovative performance scale was measured on a five-point scale ranging from 'Marginal' to 'Radical'. We employed some further adaptations to the rating scale since the pilot testing of these questions revealed difficulty concerning its comprehensibility. Many of the problems were due to the insufficient sophistication of the respondents. After a literature review on scale development and applications for respondents that are illiterate or have low levels of education, we decided to follow the procedures explained in Shah (1999) for revising the rating scale. Consequently, we came up with five phrases that correspond to the five rating levels in our product, process, and marketing innovation measurement scales. The phrases were derived based on both responses given during qualitative interviews and pilot testing. A list of the measure items are given in Appendix A. Additionally, we asked respondents to rate their influence in firm decisions as an indicator of respondent quality.

\section{Control Variables}

Four control variables were employed: Firm experience in the cluster, firm experience in the sector, education levels of respondents and firm size. Firm experience in an industrial cluster affects a firm's ability to judge the trustworthiness of its exchange partners (Dei Ottati, 2003; Bönte, 2007). Sector experience is included due to its influence on a firm's wisdom as to with whom to share information with (Şengün and Wasti, 2007) and how to use that information for innovative purposes. Education of owners and executives are said to affect knowledge sharing and innovation levels of firms (Appleyard, 1996; Khan and Manopichetwattana, 1989). As for firm size, larger and older firms are known to have more financial slack, marketing skills, research capabilities, and product development experience (Nord and Tucker, 1987), and are better able to innovate and at the same time tolerate losses from unsuccessful innovation (Damanpour, 1996). From a counter perspective, younger and smaller firms are better able to drive particularly radical innovations owing to their flexibility, and greater ability to adapt, improve, and accept change (Mintzberg, 1979; Rosenbloom and Cristensen, 1994). 


\section{Results}

\section{Qualitative Results}

According to the results of qualitative analysis, Ankara Siteler furniture cluster is characterized, among others, by relational governance mechanisms between firms, also called the 'open account basis' by cluster members. Being based on trust, this type of governance eliminates the need for costly contractual arrangements and allows for smooth running of business deals among firms. With respect to payment terms, for instance, such arrangements provide flexibility over the equation of debt-credit balance and thereby any constraints on liquidity that small furniture firms might experience. Yet, these advantages, which are to a great extent tied to trust, also have a downside. Firms complain about opportunistic tendencies such as; promises made but not delivered (i.e., adverse selection and moral hazard), exploitation of asymmetric power-dependence conditions (i.e., hold-up), and copycat designs (i.e., free riding).

Cluster firms desire to share information with each other, because they believe this may aid in the communication of practical knowledge learned through daily routine operations and help them solve problems. They also deem knowledge sharing may provide information about the future as in the kind of passing on visions and trends. However, due to concerns over opportunism and free riding as mentioned above, they cannot share knowledge with those they do not trust. Thus, personal ties and friendship is used as a guard against that risk. Consequently, knowledge is generally shared on informal occasions off the job, like during lunch or over tea/coffee.

Qualitative data suggests three fundamental types of innovation prevalent in the cluster: Product, process and marketing innovations. Product innovations are any type of 'new' product - produced either through creative state-of-the-art design and/or the use of material considered as new and/or application of a new processing technique (i.e., a new painting, polishing, coating, etc. technique). The major sources of product innovations are countries such as Italy, Spain, the USA, and France. Those to be the first to adopt such innovative designs are larger firms that are very few in number (also labeled 'lead innovators'), while smaller firms copy designs from these leading firms only after the furniture has proved to have a certain amount of market demand or simply 'made money'.

Process innovations comprise new production technology involving facility layout, adoption and use of new tools/equipment for production, and application of computerized technology (i.e., CAD, CAM, etc.) for design and/or production.

Finally, marketing innovations involve new sales methods such as the introduction of credit-based sales, new packaging and delivery methods, and/or new market entry (i.e., countries, regions, etc.) fundamentally via personal contacts.

\section{Quantitative Results}

Tables 3 and 4 report Pearson correlations between main constructs and control variables together with mean values and standard deviations for the manufacturer and retailer samples respectively. Both tables reflect more or less similar trends regarding 
significant correlations. According to this, the highest and most significant correlations among main constructs are the ones between trust and knowledge sharing. This is something expected since the 'trust' and 'knowledge sharing' constructs form the composite construct 'informal knowledge sharing' (c.f., McKnight et al., 1998). Hence, the two constructs together make one construct and therefore meant to be highly correlated. Further, there is a significant correlation between firm size and innovation in both samples reflecting the importance of firm size for innovative capability. ${ }^{[4]}$ Aside from this, the significant negative correlations between education and sector/cluster experience signify the low education levels of firm owners/managers who are as well cluster incumbents for generations. In addition, only in the manufacturer sample (Table 3) firm size is significantly correlated with education denoting that bigger manufacturing firms have better educated owners/managers. Finally, the high correlations between cluster and sector experience in both samples reflect that furniture firms in this cluster have been in the sector for a long time.

The Appendix reports composite reliability estimates (coefficient alpha, SEM reliability ${ }^{[5]}$ of the main constructs for both manufacturer and retailer samples. All composite reliability estimates are greater than or equal to 0.7 providing evidence for convergent validity of the measures (the reliability estimate of the 'innovation' construct for the manufacturer sample is slightly below the 0.7 threshold). As another measure of convergent validity, average variance extracted (AVE ${ }^{[6]}$ scores of the main constructs were computed and reported in Tables 3 and 4 for the two samples. As can be seen, most constructs score above or close to the cutoff 0.50 (Hair et al., 1995). The two exceptions are the innovation construct for the manufacturer sample and the trust construct for the retailer sample (AVE scores, 0.41 and 0.40 respectively). Hence, although our main constructs rate above the threshold with respect to Cronbach's alpha and SEM reliability estimates, two of them fall short of satisfying the AVE cutoff.

Therefore, we continue with a more stringent test of discriminant validity and compute highest shared variance (HSV) ${ }^{[7]}$ values of our main constructs and compare them with their AVE scores. As a rule of thumb, the AVE scores should be higher than HSV values to indicate discriminant validity among constructs (Zhou and Xu, 2012; Fornell and Larcker, 1981). This comparison yields the following results for the manufacturer sample: Trust (AVE: 0.68, HSV: 0.1), Knowledge sharing (AVE: 0.8, HSV: 0.1), Innovation (AVE: 0.41, HSV: 0.008). Retailer sample results are as follows: Trust (AVE: 0.4, HSV: 0.42), Knowledge sharing (AVE: 0.88, HSV: 0.42), Innovation (AVE: 0.48, HSV: 0.025). As can be observed, except for the trust construct in the retailer sample, all other constructs have HSVs smaller than AVEs suggesting discriminant validity. The trust construct in the retailer sample has its HSV with the knowledge-sharing construct. This result can be expected since the two make the composite construct informal

\footnotetext{
[4] This aspect has been shown in another study in the same cluster by Şengün and Önder (2009).

[5] This was calculated based on the formula in Hair et al. (1995: 653).

[6] This was calculated based on the formula in Hair et al. (1995: 653).

[7] HSV is calculated as the squared correlation between variables (Fornell and Larcker, 1981).
} 
knowledge sharing and hence are theoretically related (c.f., McKnight et al., 1998). Further, as mentioned in the background on the setting and hypotheses development sections, furniture makers in the cluster under study do not like to share information with those they do not trust. Thus, they might qualitatively think of trust to be the same as knowledge sharing. Another indication of discriminant validity is the amount of bivariate correlations between variables (as a rule of thumb they should be significantly different from 1.0) (Hair et al., 1995). As can be seen in Tables 3 and 4, all the bivariate two-tailed correlations among main constructs are below the 0.7 rule of thumb, signifying discriminant validity (Tabachnick and Fidell, 2001:84).

Normality tests of the construct variables in the two samples revealed a severe left skewness for the trust variable in the manufacturer sample and necessary adjustments were made involving reflection and $\log$ transformation of the items.

Table 3

Descriptive Statistics, Average Variance Extracted (AVE) Scores and Pearson Correlations for the Manufacturer Sample $(n=219)$

\begin{tabular}{|c|c|c|c|c|c|c|c|c|c|c|}
\hline Variable & Mean & S.D. & $A V E$ & 1 & 2 & 3 & 4 & 5 & 6 & 7 \\
\hline Interfirm trust & 3.99 & 0.93 & 0.68 & 姜 & & & & & & \\
\hline Knowledge sharing & 3.14 & 1.16 & 0.80 & $.327^{* *}$ & 羊 & & & & & \\
\hline Innovation & 2.35 & 0.98 & 0.41 & .010 & -.090 & 姜 & & & & \\
\hline Sector experience & 23.10 & 10.13 & N.A. & .052 & .023 & -.035 & 羊 & & & \\
\hline Cluster experience & 22.55 & 10.58 & N.A. & .070 & .027 & -.043 & $.945 * *$ & 羊 & & \\
\hline Education level & 2.16 & 1.60 & N.A. & -.044 & -.089 & .073 & $-.469 * *$ & $-.456^{* *}$ & 羊 & \\
\hline Firm size & 3.88 & 3.82 & N.A. & -.107 & -.107 & $.202 * *$ & -.097 & -.115 & $.293 * *$ & 姜 \\
\hline
\end{tabular}

**: Correlation is significant at the 0.01 level.

Table 4

Descriptive Statistics, Average Variance Extracted (AVE) Scores and Pearson Correlations for the Retailer Sample $(n=137)$

\begin{tabular}{|c|c|c|c|c|c|c|c|c|c|c|}
\hline Variable & Mean & S.D. & $A V E$ & 1 & 2 & 3 & 4 & 5 & 6 & 7 \\
\hline Interfirm trust & 3.30 & 0.90 & 0.40 & 单 & & & & & & \\
\hline Knowledge sharing & 3.72 & 1.00 & 0.88 & $.656^{* *}$ & 羊 & & & & & \\
\hline Innovation & 3.10 & 1.00 & 0.48 & .157 & -.012 & 羊 & & & & \\
\hline Sector experience & 22.20 & 11.16 & N.A. & -.067 & -.011 & -.012 & 兰 & & & \\
\hline Cluster experience & 21.74 & 11.43 & N.A. & -.091 & -.048 & -.023 & $.962^{* *}$ & 姜 & & \\
\hline Education level & 3.21 & 2.28 & N.A. & .091 & .027 & .121 & $-.594 * *$ & $-.593 * *$ & 羊 & \\
\hline Firm size & 13.58 & 37.44 & N.A. & .036 & -.059 & $.253 * *$ & -.094 & -.088 & .089 & 姜 \\
\hline
\end{tabular}

**: Correlation is significant at the 0.01 level. 
Data were analyzed using LISREL 8.3 and structural equation modeling (SEM) was used for testing hypotheses for the two firm samples. The choice of SEM was indicated by the theoretical model used in the study as specified in Figure 1. As the figure denotes, the sequential conceptual relationship between trust and knowledge sharing and then their association to innovative performance could only be handled by a statistical tool that allows for the testing of such a model. The four control variables were treated as follows: First the partial correlations of the observed indicators were computed controlling for experience in the cluster, experience in the sector, education and firm size. Then this correlation matrix was used as input data for the confirmatory structural model to be analyzed by LISREL 8.3. The SEM path results are presented in Figures 2 and 3. The fit indices suggest perfect fit between the conceptual model and the data (chi-square $=22.11$; d.f. $=18$; GFI $=0.98$; $\mathrm{CFI}=0.99$; IFI $=0.99$; NFI $=0.97$; $\mathrm{RMSEA}=0.032$; $\mathrm{RMR}=0.044)$ for the manufacturer sample, and good fit (chi-square $=97.51$; d.f. $=$ 25; GFI $=0.88 ; \mathrm{CFI}=0.88 ; \mathrm{IFI}=0.88 ; \mathrm{NFI}=0.87 ; \mathrm{RMSEA}=0.095 ; \mathrm{RMR}=0.085$ ) for the retailer sample. The relatively inferior results for the retailer sample may be due to the size of this sample. Although there is no correct sample size, some approaches suggest using more than 200 to get robust results while doing SEM analysis (Hair et al., 1995:637). SEM results for the manufacturer and retailer samples (Figures 2 and 3, respectively) show a significant association between trust and knowledge sharing ( $\beta=$ $0.36, \mathrm{p}<0.05 ; \mathrm{R}^{2}=0.13 ; \beta=0.83, \mathrm{p}<0.05 ; \mathrm{R}^{2}=0.69$, respectively). Therefore, $\mathrm{H} 1, \mathrm{H} 1 \mathrm{a}$ and $\mathrm{H} 1 \mathrm{~b}$ are supported. SEM results for the manufacturer and retailer samples (Figures 2 and 3) show no significant association between knowledge sharing and innovative performance $\left(\beta=-0.11, p>0.05 ; R^{2}=0.012 ; \beta=-0.01, p>0.05 ; R^{2}=0.00\right.$, respectively). Therefore $\mathrm{H} 2, \mathrm{H} 2 \mathrm{a}$ and $\mathrm{H} 2 \mathrm{~b}$ are not supported.

Overall, therefore, our results lead to a rejection of our general theoretical hypothesis that informal knowledge sharing (i.e., trust based knowledge sharing) will positively influence innovative performance.

Figure 2

\section{SEM Measurement Model - Informal Knowledge Sharing and Innovation for the Manufacturer Sample}

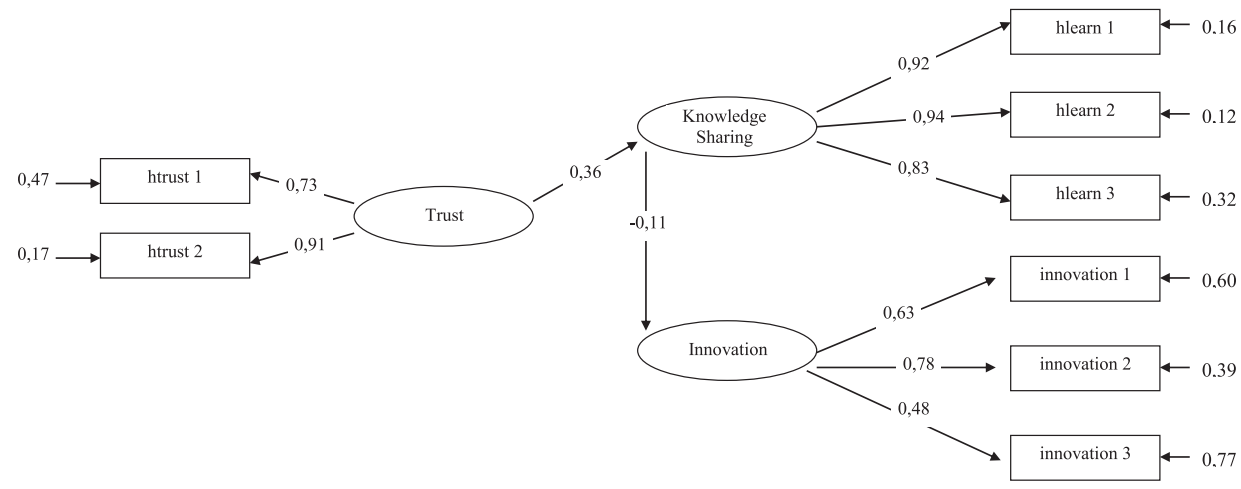


Figure 3

\section{SEM Measurement Model - Informal Knowledge Sharing and Innovation for the Retailer} Sample

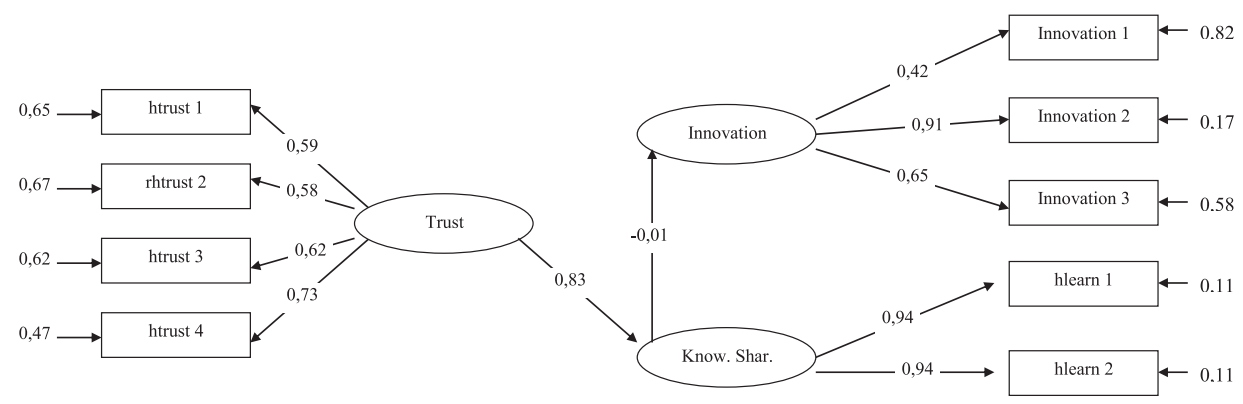

\section{Discussion}

This study analyzed the impact of informal knowledge sharing among firms in a furniture cluster on their individual innovative performance. By informal knowledge sharing we meant to imply the more or less automatic, haphazard, indirect, unintended or accidental knowledge accrued by cluster firms via mere membership in the cluster or 'being there' (Bathelt, Malberg, and Maskell, 2004; Tallman, Jenkins, Henry, and Pinch 2004). Our study findings did not show any significant association between informal knowledge sharing and innovative performance. Below, we discuss possible explanations for this finding.

Numerous studies on industrial clusters suggest that political, social and institutional factors are as important for the production of innovation as is the diffusion and sharing of knowledge (Appleyard, 1996; Humphrey and Schmitz, 2002; Tallman et al., 2004). To give an example, researchers elaborate on the possible effects of the parameters of the local setting such as the developmental stage of the cluster (Staber, 1998) or the role of the state in encouraging regional industrial development (Parker and Tamaschke, 2005). In a similar vein, the favorability of various environmental conditions (Herbig, 1994) and the dynamism of the cluster as perceived by its members (Tushman and Romanelli, 1985; Brown and Eisenhardt, 1997) are considered as factors of prominence that enable firms in a cluster to be innovative. Other researchers focus on the role of shared visions and aspirations toward collective goals among main stakeholders in the cluster as important resources for learning and innovation (Miller, Besser, and Malshe, 2007; Molina-Morales and Martinez-Fernandez, 2006; Beerepoot, 2008). This perspective is similar to the idea of the significance of a strong 'strategic intent', meaning, a collective vision for the advancement of the cluster as a whole, which may allow firms to break out their current conditions and embrace innovations (Humphrey and Schmitz, 1998, 2002).

When we investigate the cluster under study, we observe that our particular case is away from being able to satisfy the institutional conditions needed for innovation such as those mentioned above. According to the qualitative interviews, with respect to the role of the state, cluster members generally complain about lack of governmental support 
for the development of the region. Resultantly, most firms see the outlook of the cluster quite obscure. According to them, the fundamental reason behind this pessimism is the lack of interest by governmental bodies in the problems of the cluster. One respondent claims that 'it is as though the cluster firms have an invisible shell around them, which they cannot break' and that this prevents them from attacking the market aggressively.

As per the favorability of environmental conditions and dynamism of the cluster, the views are again bleak. Respondents suggest that production spaces are limited and most workshops operate in multi-storey buildings that limit the installation of state-of-the art machines for greater scale production. They also note about the unproductive practices by members such as not keeping official records to document periodical income, which keeps them from raising funds from financial institutions. Another such practice is reported as the wrong reinvestment policies that lead firms to waste their earnings on luxurious consumption than growing their businesses. Moreover, craftsmen are said to lack self-development motives, most of them depending on a single or few related skills and having little or no formal education. Despite this fact, they are generally not interested in the training programs offered by trade associations.

Considering shared visions, aspirations and strategic intent, members firms do not seem to have collective strategic initiatives. As a manifestation of this, most firms do not have access and are not inserted into global networks. Theoretically, such global networks have the potential to help firms upgrade their innovations and improve their product, process and marketing intelligence (Humphrey and Schmitz, 2002; Eraydin and Köroğlu, 2005). Also, as Bathelt et al. (2004) argue, such external linkages may feed new and valuable knowledge residing elsewhere into the locale. This, in turn, will enhance the innovation generating potential of within cluster informal knowledge sharing (i.e., 'local buzz') through its enrichment with complementary, heterogeneous and broader extra-local knowledge.

Our respondents claim that only larger scale firms have extra local linkages. As they suggest, these firms prevent smaller scale firms from being integrated into such alternative trade networks, as they desire to attain a stronger bargaining power over them. In a recent paper on a furniture cluster, Mesquita and Lazzarini (2008) propose ways out of such adversities. Their recommendation is to promote relational governance in the form of trust and cooperation between cluster members so as to improve inter-firm coordination and attain collective efficiencies. Turning to our case, we cannot say that such cooperative prospects are promising. Actually, previous research shows a rather low level of trust and cooperation between cluster members and a very high level of competition in return (Öz, 2004; Ankara Kalkınma Ajans1, 2012).

Problems very similar to the ones mentioned above are echoed in a recent study in the cluster by Ankara Development Agency (2012). An interesting finding of this study is that although most member firms strongly advocate the initiation of innovative attempts, they approach the idea hesitantly when such attempts require their collective undertakings and cooperation.

In view of the above, it can be concluded that when institutional conditions fall short of what Dei Ottati calls, the 'extraordinary concertation' (2003:199) of efforts to support 
the production of innovation, within cluster informal knowledge sharing per se does not deliver innovative outcomes. While cluster firms may share knowledge and believe in its innovative potential, their 'industrial milieu' may not be supportive of this potential.

\section{Conclusions and Implications}

This study investigated the influence of informal knowledge sharing on innovative performance of individual firms in an industrial cluster. The results do not find evidence of a significant correlation between informal knowledge sharing and firm-level innovation. Hence, the study does not provide support for the theoretical claim that 'knowledge in the air' or indirect knowledge spillovers in industrial clusters breed innovation (e.g., Becattini, 2004; Bellandi, 1989; Cooke, Gomez, and Etxebarrria, 1997; Dei Ottati, 1994, 2003; Marshall, 1952), which is almost taken-for-granted in the literature (Arıkan, 2009; Bathelt et al., 2004). More specifically, sharing knowledge that is not aimed at a specific purpose and is therefore indirect and haphazard does not affect innovation. On the other hand, such an absence of association between knowledge sharing and innovation urges us to turn to assess the relevance of supporting institutional factors in the cluster as an explanation. Our qualitative findings paint an obscure picture as to the socio political and economic conditions in the cluster. According to this, cluster firms lack shared visions and aspirations, a strategic intent and motivation for change and development, trust and cooperation, state support for regional development, and the necessary physical conditions (i.e., facility layout) to deliver innovative outcomes. As such, the macro level conditions of the cluster fall short of supporting micro level firm outcomes.

We believe the results of the study constitute a timely response to a call in popular press towards more verification in science (Economist, October 19, 2013). According to this, 'insignificant' results do not find their way in published papers because they are not so 'striking', are 'humdrum' or 'uninteresting'. This in turn leads to a 'failure to report failures' which is as much necessary in the search for truth as proven hypotheses. Hence, by verifying the insignificance of a theoretically sound hypothesis, the study opens the door to questioning earlier theoretical assumptions on the effectiveness of knowledge spillovers on innovation in industrial clusters.

An important implication for managers facing unfavorable institutional conditions in clusters may be to rely more on direct, purposive knowledge sharing that is aimed at exchanging value-for-value than otherwise. In this respect, sharing knowledge with buyers or suppliers may be preferred, where the focus is to achieve an explicit purpose such as receiving a kind of compensation in return.

Our results point at possible interactions between macro or cluster level elements and micro or firm level outcomes. In this respect, future research might measure these macro institutional factors explicitly to show their influence on and interactions with firm level innovative performance. Another ripe future direction may be to test the influence of informal knowledge sharing on innovation in clusters with favorable or supportive institutional environments to provide empirical evidence on the influence of indirect knowledge spillovers on innovation, so far a neglected field of study. 
Some methodological problems of the study need to be addressed. First, the questions were asked to only one side, although a matched sample would provide better estimates of the relationship between the variables. Secondly, the questionnaire relies on self-report responses, which may bias answers, particularly toward the socially desirable response. Third, as most respondents were less educated and not familiar with tests, adjustments had to be made to the innovation measure. The sentences used as explanations for the innovation rating scale are thus presumed to correspond to the numerics they stand for. Finally, the fact that the study was done in a single cluster of a single country raises the usual reservations about the generalizability of the findings.

\section{References}

Adler, P.S. and Kwon, S.W. (2002). "Social Capital: Prospects for a New Concept," Academy of Management Review, 27(1): 17-40.

Amara, N. and Landry, R. (2005). "Sources of Information as Determinants of Novelty of Innovation in Manufacturing Firms: Evidence from the 1999 Statistics Canada Innovation Survey," Technovation, 25: 245-259.

Ankara Kalkınma Ajansı, (2012). Siteler, Mobilya ve Ankara.

Appleyard, M.M. (1996). "How does Knowledge Flow? Interfirm Patterns in the Semiconductor Industry," Strategic Management Journal, 17: 137-154.

Arıkan, A. (2009). "Inter-firm Knowledge Exchanges and the Knowledge Creation Capability of Clusters," 34(4): 658-676.

Asheim, B.T. (2002). "Temporary Organizations and Spatial Embedded- ness of Learning and Knowledge Creation," Geografiska Annaler: Series B Human Geography, 84: 111-124.

Asheim, B T. and Coenen, L. (2004). The Role of Regional Innovation Systems in a Globalizing Economy: Comparing Knowledge Bases and Institutional Frameworks of Nordic Clusters. German Institute for Economic Research conference, June 4-5, Berlin.

Asheim, B.T., Coenen, L., and Svensson-Henning, M. (2003). "Nordic SMEs and Regional Innovation Systems," Report prepared for the Nordic Industrial Fund, Center for Innovation and Commercial Development.

Audretsch, D. and Feldman, M. (1996). "Knowledge Spillovers and the Geography of Innovation and Production," American Economic Review, 86(3): 630-640.

Baptista, R. and Swann, P. (1998). “Do Clusters Innovate More?” Research Policy, 27: 525-540.

Bathelt, H., Malmberg, A., and Maskell, P. (2004). "Clusters and Knowledge: Local Buzz, Global Pipelines and the Process of Knowledge Creation," Progress in Human Geography, 28: 31-56.

Becattini, G. (2004). Industrial Districts: A New Approach to Industrial Change. Cheltenham: Edward Elgar Publishing.

Bellandi, M. (1989). "The Industrial District in Marshall." in E.A. Goodman., J. Bamford, and P. Saynor (eds.), Small Firms and Industrial Districts in Italy: 136-152. London: Routledge.

Beerepoot, N. (2008). "Diffusion of Knowledge and Skills through Labor Markets: Evidence from the Furniture Cluster in Metro Cebu," Entrepreneurship and Regional Development, 20:67-88.

Berg, B. (1998). Qualitative Research Methods. Boston: Allyn and Bacon. 
Bönte, W. (2007). "Inter-firm Trust in Buyer-supplier Relations: Are Knowledge Spillovers and Geographical Proximity Relevant?," Journal of Economic Behavior and Organization, doi: 10.1016/j. jebo.2006.12.004.

Brown, S.L. and Eisenhardt, K.M. (1997) "The Art of Continuous Change: Linking Complexity Theory and Time-pased Evolution in Relentlessly Shifting 0rganizations," Administrative Science Quarterly, 42(1): 1-34.

Caloghirou, Y., Kastelli, I., and Tsakanikas, A. (2004). "Internal Capabilities and External Knowledge Sources: Complements or Substitutes for Innovative Performance," Technovation, 24: 29-39.

Coffey, A. and Atkinson, P. (1996). Making Sense of Qualitative Data: Complementary Research Strategies. Thousand Oaks: Sage.

Cooke M., Gomez, U., and Etxebarria, G. (1997). "Regional Systems of Innovation: Institutional and Organizational Dimensions," Research Policy, 26: 474-491.

Damanpour, F. (1996). "Organizational Complexity and Innovation: Developing and Testing Multiple Contingency Models,” Management Science, 42(5): 693-716.

Dei Ottati, G. (1994). "Trust, Interlinking Transactions and Credit in the Industrial District," Cambridge Journal of Economics, 18: 529-546.

------, (2003). "Trust, Interlinking Transactions and Credit in the Industrial District," in M. Becattini., G. Dei Ottai, and F. Sforzi (eds.), From Industrial Districts to Local Development: 108-130. UK: Edward Elgar.

Dyer, J.H. and Singh. H. (1998). "The Relational View: Cooperative Strategy and Sources of Interorganizational Competitive Advantage," Academy of Management Review, 23: 660-679.

Economist, (2013). "How Science goes Wrong?" October 19.

Eraydın, A. and Armatl1-Köroğlu, B. (2005). "Innovation, Networking and the New Industrial Clusters: The Characteristics of Networks and Local Innovation Capabilities in the Turkish Industrial Clusters," Entrepreneurship and Regional Development, 17: 237-266.

Fornell, C. and Larcker, D.F. (1981). "Evaluating Structural Equation Models with Unobservable Variables and Measurement Error," Journal of Marketing Research, 18(1): 39-50.

Frost, T.S. (2001). "The Geographic Sources of Foreign Subsidiaries' Innovations," Strategic Management Journal, 22: 101-123.

Ganesan, S. (1994). "Determinants of Long-term Orientation in Buyer-seller Relationships," Journal of Marketing, 58: 1-19.

Geenhuizen, M. and Indarti, N. (2006). "Knowledge and Innovation in the Indonesian Artisanal Furniture Industry," 46th Congress of the European Regional Science Association (ERSA 2006), Volos, Greece, 30th August-3rd September.

Gellynck, X., Vermeire, B., and Viaene, J. (2007).” Innovation in Food Firms: Contribution of Regional Networks within the International Business Context," Entrepreneurship and Regional Development, 19: 209-226.

Gilbert, B.A., McDougall, P.P., and Audretsch, D.B., (2008). "Clusters, Knowledge Spillovers and New Venture Performance: An Empirical Examination," Journal of Business Venturing, 23: 405-422.

Hair, J.F., Anderson, R.E., Tatham, R.L., and Black, W.C. (1995). Multivariate Data Analysis with Readings. Englewood Cliffs, NJ: Prentice Hall. 
Hansen, M.T. (1999). "The Search Transfer Problem: The Role of Weak Ties in Sharing Knowledge across Organizational Subunits," Administrative Science Quarterly, 44: 82-111.

Herbig, P.A. (1994). The Innovation Matrix: Culture and Structure Prerequisites Innovation. Quorum: Connecticut.

Humphrey, J. and Schmitz, H. (2002). "How does Insertion in Global Value Chains Affect Upgrading in Industrial Clusters?," Regional Studies, 36(9): 1017-1027.

Ibrahim, S. and Fallah. M.H. (2005). "Drivers of Innovation and Influence of Technological Clusters," Engineering Management Journal, 17(3): 33-41.

Isaksen, A. (2001). "Building Regional Innovation Systems: Is Endogenous Industrial Development Possible in the Global Economy?," Canadian Journal of Regional Science, 24(1): 101-120.

Jaffe, A.B., Trajtenberg, M., and Henderson, R. (1993). "Geographic Localization of Knowledge Spillovers as Evidenced by Patent Citations." The Quarterly Journal of Economics, August: 577-598.

Jap, S.D. and Ganesan, S. (2000). "Control Mechanisms and the Relationship Life Cycle: Implications for Safeguarding Specific Investments and Developing Commitment," Journal of Marketing Research, 37: 227-245.

Kale, P., Singh, H., and Perlmutter, H. (2000). "Learning and Protection of Proprietary Assets in Strategic Alliances: Building Relational Capital,” Strategic Management Journal, 21: 217-237.

Keeble, D. and Wilkinson, F. (1998). "Collective Learning and Knowledge Development in the Evolution of Regional Clusters of High Technology SMEs in Europe," Regional Studies, 33: 295-303.

Khan, M. and Manopichetwattana, V. (1989). "Innovative and Non-innovative Small Firms: Types and Characteristics," Management Science, 35(5): 597-606.

Krackhardt, D. and Hanson, J.R. (1993). "Informal Networks: The Company behind the Charts," Harvard Business Review, 71: 104-112.

Lavie, D. (2006). "The Competitive Advantage of Interconnected Firms: An Extension of the Resourcebased View," Academy of Management Review, 31(3): 638-658.

Lawson, C. (1997). "Territorial Clustering and High Technology Innovation: From Industrial Districts to Innovative Milieu" ESRC Centre for Business Research Working Paper 54 University of Cambridge.

-----, (1999). “Towards a Competence Theory of the Region. Cambridge Journal of Economics, 23: 151-166.

Leonardi, R. (1995). "Regional Development in Italy: Social Capital and the Mezzogiorno," Oxford Review of Economic Policy, 11(2): 165-179.

Lundvall, B.A. (1992). National Systems of Innovation: Towards a Theory of Innovation and Interactive Learning. London: Printer.

Marshall, A. (1952). Principles of Economics. London: Macmillian.

McAllister, D.J. (1995). “Affect and Cognition Based as Foundations for Interpersonal Cooperation in Organizations. Academy of Management Journal, 38(1): 24-59.

McKnight, D.H., Cummings, L.L., and Chervany, N.L. (1998). "Initial Trust Formation in New Organizational Relationships," Academy of Management Review, 23(3): 473-490.

Mesquita, L.F. and Lazzarini, S.G. (2008). "Horizontal and Vertical Relationships in Developing Economies: Implications for SMEs Access to Global Markets. Academy of Management Journal, 51(2): 359-380. 
Miller, N.J., Besser, T., and Malshe, A. (2007). "Strategic Networking among Small Businesses in Small US Communities,” International Small Business Journal, 25(6): 631-665.

Mintzberg, H. (1979). The Structuring of Organizations. Englewood Cliffs, NJ: Prentice-Hall.

Molina-Morales, F.X. and Martnez-Fernandez, M.T. (2006). Industrial Districts: Something More than a Neighborhood. Entrepreneurship and Regional Development," 18: 503-524.

Nahapiet, J. and Ghoshal, S. (1998). "Social Capital, Intellectual Capital, and the Organizational Advantage," Academy of Management Review, 23(2): 242-266.

Nord, W.R. and Tucker. S. (1987). Implementing Routine and Radical Innovation. Lexington. MA: Lexington Books.

Oinas, P. (1999). "Activity-specificity in Organizational Learning: Implications for Analyzing the Role of Proximity," GeoJournal, 49: 363-72.

Oslo Manual. (2005). Guidelines for Collecting and Interpreting Innovation Data, $3^{\text {rd }}$ edition. OECD and Eurostrat Publications.

Öz, Özlem. (2004). Clusters and Competitive Advantage: The Turkish Experience. London:Routledge.

Özen, Ş., Işık, N.E., Uysal, Ö.Ö., Şengün, A. E., Aksoy,B., Çakar, M., and Akış, B. (2007). Işs Kültürü ve Örgütler Arası İlişkilerin Örgütsel Performansa Etkileri: Ankara Mobilyacılar Sitesi Örneği. TÜBİTAK, SOBAG: Proje No: 105K168.

Pardo, T.A., Cresswell, A.M., Zhang, J., and Thompson. F. (2001). "Interorganizational Knowledge Sharing in Public Sector Innovations," Academy of Management Proceedings, 3-8 August, Washington D.C.

Parker, R. and Tamaschke, L. (2005)." Explaining Regional Departures from National Patterns of Industry Specialization: Regional Institutions, Policies and State Coordination," Organization Studies, 26(12): 1787-1807.

Porter, M. (1998). "Clusters and the New Economics of Competition," Harvard Business Review, 76(6): 77-90.

Rabelotti, R. (1995). "Is There an Industrial District Model? Footwear Districts in Italy and Mexico Compared," World Development, 23(1), 29-41.

Revilla-Diez, J. (2002). "Metropolitan Innovation Systems: A Comparison between Barcelona, Stockholm and Vienna." International Regional Science Review, 25(1): 63-85.

Rosenbloom, R.S. and Christiensen, C.M. (1994). "Technological Discontinuities, Organizational Capabilities, and Strategic Commitments," Industrial and Corporate Change, 3(3): 655-685.

Saxenian, A.L. (1994). Regional Advantage. Cambridge, MA: Harvard University Press.

Schmitz, H. (1995). "Collective Efficiency: Growth Path for a Small-scale Industry." Journal of Development Studies, 31(4): 529-561.

------, (1999). "Collective Efficiency and Increasing Returns," Cambridge Journal of Economics, 23: 465-483.

Schultz, M. and Hatch, M.J. (1996). "Living with Multiple Paradigms: The Case of Paradigm Interplay in Organizational Culture Studies," Academy of Management Review, 21(2): 529-557.

Şengün, A.E. and Wasti, S.N.. (2007). "Trust, Control, and Risk: A Test of Das and Teng's Conceptual Framework," Group and Organization Management, 32(4): 430-464. 
Şengün, A.E. and Önder, Ç. (2009). "Endüstriyel Kümelerde Yenilikçilik: Firma Özellikleri Etkili mi?” Yönetim Araştırmalar Dergisi, 9(1): 5-34.

Shah, A.A. (1999). "Measuring Attitudes in Test-alien Cultures: When Illeteracy and Unfamiliarity do not Matter." Asian Journal of Social Psychology, 2: 245-264.

Spencer, J.W. (2003). “Firms' Knowledge Sharing Strategies in the Global Innovation System: Empirical Evidence from the Flat Panel Display Industry.” Strategic Management Journal, 24: 217-233.

Staber, U. (1998). "Inter-firm Co-operation and Competition in Industrial Districts," Organization Studies, 19(4): 701-724.

Storper, M. (1995). "The Resurgence of Regional Economies, Ten Years Later: The Region as a Nexus of Untraded Interdependencies," European Urban and Regional Studies, 2(3): 191-221.

Tabachnick, B.G. and Fidell, L.S. (2001). Using Multivariate Statistics. Boston: Allyn Bacon.

Tallman, S., Jenkins, M., Henry, N., and Pinch, S. (2004). "Knowledge, Clusters and Competitive Advantage," Academy of Management Review, 29(2): 258-271.

Tushman, Michael. L. and Romanelli, E. (1985). "Organizational Evolution: A Metamorphosis Model of Convergence and Reorientation," in L.L. Cummings and B.M. Staw (eds.), Research in Organizational Behavior: 171-222. Greenwich, CT: JAI Press.

Visser, E.J. (1999). "A Comparison of Clustered and Dispersed Firms in the Small-scale Clothing Industry of Lima,” World Development, 27(9): 1553-1570.

Weerawardena, J. (2003). "Exploring the Role of Market Learning Capability in Competitive Strategy," European Journal of Marketing, 37(3-4): 407-429.

You, J.I. and Wilkinson, F. (1994). "Competition and Cooperation: Toward Understanding Industrial Districts," Review of Political Economy, 6: 259-278.

Zaheer, A., McEvily, B., and Perrone, V. (1998). "Does Trust Matter? Exploring the Effects of Interorganizational and Interpersonal Trust on Performance," Organization Science, 9: 141-159.

Zhou, K Z. and Xu, D. (2012). "How Foreign Firms Curtail Local Supplier Opportunism in

China: Detailed Contracts, Centralized Control, and Relational Governance," Journal of International Business Studies, 43: 677-692. 


\section{APPENDIX}

\section{Measure Items}

$\underline{\text { Interfirm Trust for manufacturers }}(2$ items, Cronbach alpha $=0.81$, SEM reliability $=0.81$ )

1. This manufacturer is like a friend.

2. We share ideas and feelings with this manufacturer.

Knowledge Sharing for manufacturers (3 items, Cronbach alpha $=0.92$, SEM reliability $=0.92$ )

1. We learned or acquired some new or important information from this manufacturer.

2. We learned or acquired some critical capability or skill from this manufacturer.

3. This manufacturer has helped our company to enhance our existing capabilities/skills.

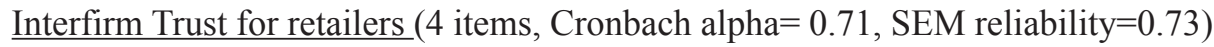

1. This retailer is like a friend.

2. We share ideas and feelings with this retailer.

3. I would not do business with this retailer unless all the conditions are prespecified. (reverse coded).

4. This retailer may make short-term sacrifices for long-term gains.

$\underline{\text { Knowledge Sharing for retailers }}$ ( 3 items, Cronbach alpha $=0.94$, SEM reliability $=0.94$ )

1. We share any type of information with this retailer that we think would benefit each other.

2. We keep each other informed about events or changes that we think might impact our business with this retailer.

Scale: 1 -strongly disagree, 2-disagree, 3 -neither agree nor disagree, 4-agree, 5 -strongly agree.

Innovation ( 3 items, Cronbach alpha $=0.67$ for manufacturers and 0.70 for retailers; SEM reliability $=0.67$ for manufacturers and 0.71 for retailers)

Innovation refers to any NEW IDEA that your firm adopts for its products, production processes, and marketing activities, which directly or indirectly ADDS VALUE TO THE FIRM.

Please think about the innovative activities your firm has undertaken during the PAST FIVE YEARS. Please circle the number, which corresponds to the degree of innovation for each of the following statements. 


\section{Product innovations}

Some examples: a) improving existing products b) creating entirely new products 1. Product improvements have been mainly...

$\begin{array}{lllllll}\text { Incremental } & 1^{[1]} & 2 & 3^{[2]} & 4 & 5 & \text { Radical }\end{array}$

\section{Production process innovations}

Some examples a) introducing computer-based production applications b) automated material handling c) improvements in machine and equipment

2. Process innovations introduced by our firm during the last five years have been... $\begin{array}{lllllll}\text { Limited } & 1 & 2 & 3 & 4 & 5^{[3]} & \text { Extensive }\end{array}$

\section{Marketing innovations}

Some examples a) introducing new pricing methods b) entering a new market c) utilizing new packaging and delivery methods

3. Marketing innovations have been mainly...

$\begin{array}{lllllll}\text { Incremental } & 1^{[4]} & 2 & 3 & 4 & 5 & \text { Radical }\end{array}$

Sector Experience (1 item, Cronbach alpha= N.A.)

1. For how long have you been working in the furniture sector?

District Experience $(1$ item, Cronbach alpha $=$ N.A. $)$

1. For how long have you been working in this cluster?

Firm Size (1 item, Cronbach alpha= N.A.)

1. How many people work in this firm including you?

Education $(1$ item, Cronbach alpha $=$ N.A. $)$

1. Please indicate your education level:

Primary School

Junior high school

High School

Vocational High School

University

Grad School

Respondent quality ( 1 item, Cronbach alpha= N.A.)

To what extent are you effective on your firm's decisions?

$\begin{array}{llllllll}\text { Not so effective } & 1 & 2 & 3 & 4 & 5 & \text { Very effective }\end{array}$

\footnotetext{
[1] Sample phrase: "We have made negligible changes in our products."

[2] Sample phrase: "We have made mediocre changes in our products."

${ }^{[3]}$ Sample phrase: "We have made extensive changes in our production methods."

${ }^{[4]}$ Sample phrase: "We have made very little changes in our sales and marketing methods."
} 